Provided for non-commercial research and education use. Not for reproduction, distribution or commercial use.

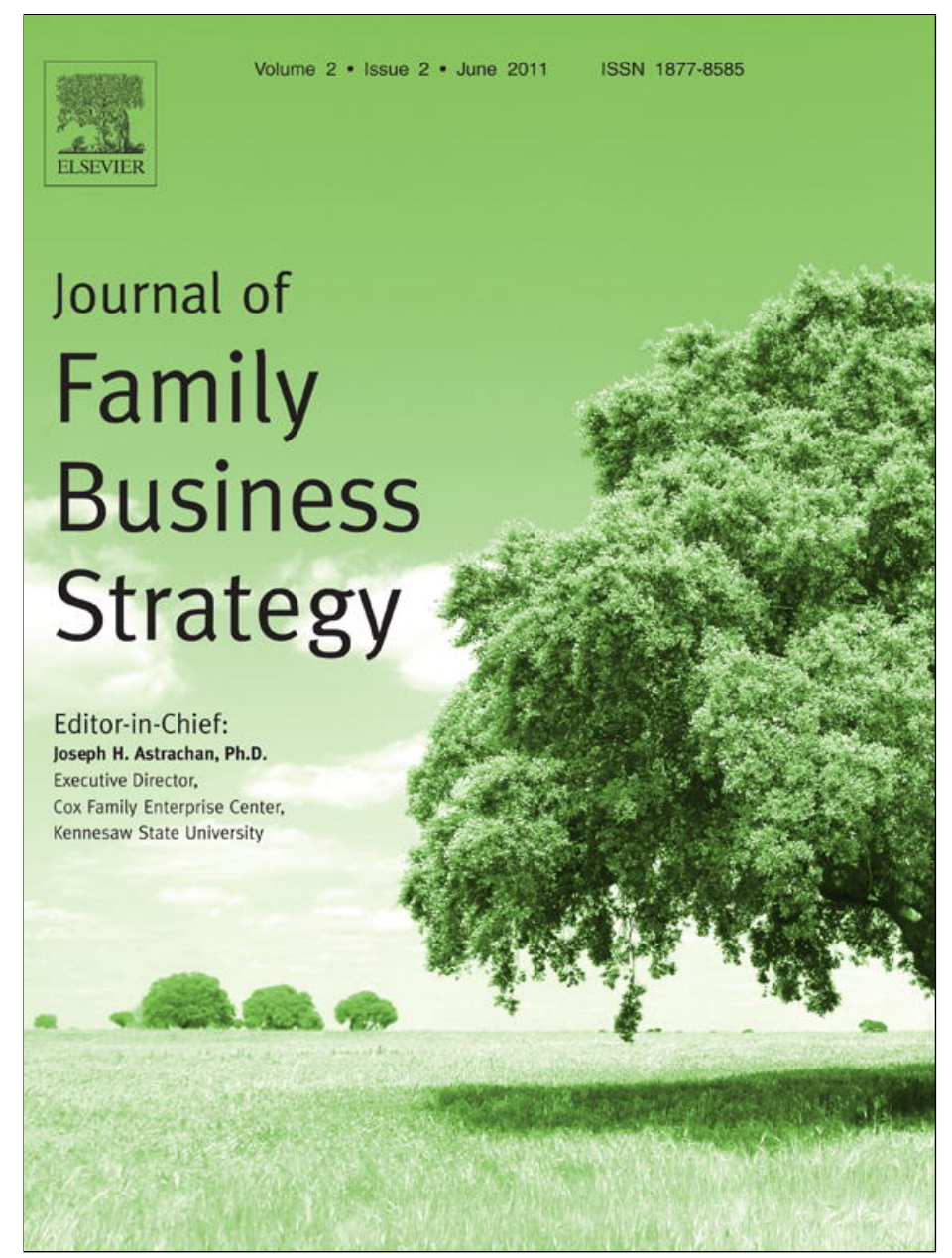

This article appeared in a journal published by Elsevier. The attached copy is furnished to the author for internal non-commercial research and education use, including for instruction at the authors institution and sharing with colleagues.

Other uses, including reproduction and distribution, or selling or licensing copies, or posting to personal, institutional or third party websites are prohibited.

In most cases authors are permitted to post their version of the article (e.g. in Word or Tex form) to their personal website or institutional repository. Authors requiring further information regarding Elsevier's archiving and manuscript policies are encouraged to visit:

http://www.elsevier.com/copyright 


\title{
Affective commitment and job satisfaction among non-family employees: Investigating the roles of justice perceptions and psychological ownership
}

\author{
Philipp Sieger ${ }^{\mathrm{a}, 1, *}$, Fabian Bernhard ${ }^{\mathrm{b}, 1,2}$, Urs Frey ${ }^{\mathrm{a}, 3}$ \\ ${ }^{a}$ Center for Family Business (CFB-HSG), University of St. Gallen, Dufourstrasse 40a, 9000 St. Gallen, Switzerland \\ b INSEEC Business School - Grande École de Commerce, INSEEC Research Center, 27 Avenue Claude Vellefaux, 75010 Paris, France
}

\section{A R T I C L E I N F O}

\section{Article history:}

Received 25 February 2011

Received in revised form 15 March 2011

Accepted 16 March 2011

\section{Keywords:}

Commitment

Job satisfaction

Justice perceptions

Psychological ownership

Non-family employees

\begin{abstract}
A B S T R A C T
Due to numerous characteristics often attributed to family firms, they constitute a unique context for non-family employees' justice perceptions. These are linked to non-family employees' pro-organizational attitudes and behaviors, which are essential for family firms' success. Even though scholarly interest in non-family employees' justice perceptions has increased, more research is still needed, also because the mechanism connecting justice perceptions and favorable outcomes is not fully understood yet. We address this gap by explicitly investigating non-family employees' justice perceptions and by introducing psychological ownership as a mediator in the relationships between justice perceptions (distributive and procedural) and common work attitudes (affective commitment and job satisfaction). Our analysis of a sample of 310 non-family employees from Germany and German-speaking Switzerland reveals that psychological ownership mediates the relationships between distributive justice and affective commitment as well as job satisfaction. This represents valuable contributions to family business research, organizational justice and psychological ownership literature, and to practice.
\end{abstract}

(c) 2011 Elsevier Ltd. All rights reserved.

\section{Introduction}

Family firms are often linked with characteristics such as paternalistic-autocratic rule, founder-centric cultures, lack of delegation, ingroup-outgroup perceptions of non-family employees, altruism, and nepotism (cp. Barnett \& Kellermanns, 2006; Kelly, Athanassiou, \& Crittenden, 2000; Padgett \& Morris, 2005; Schein, 1983; Schulze, Lubatkin, Dino, \& Buchholtz, 2001). These unique aspects constitute potential sources of injustice perceptions of non-family employees (Barnett \& Kellermanns, 2006; Blondel, Carlock, \& Heyden, 2000; Carsrud, 2006). This is critical for family firms, as employees' justice perceptions have been linked to positive work outcomes such as affective commitment (cp. Allen \& Meyer, 1990; Meyer, Stanley, Herscovitch, \& Topolnytsky, 2002; Van Dyne \& Pierce, 2004) and job satisfaction (e.g., Colquitt, Conlon, Wesson, Porter, \& Ng, 2001; Janssen \& Van Yperen, 2004; Judge, Thoresen, Bono, \& Patton, 2001). Fostering these attitudes among non-family employees is essential to family firms' success and survival

\footnotetext{
* Corresponding author. Tel.: +41 71224 7100; fax: +41 712247101 .

E-mail addresses: philipp.sieger@unisg.ch (P. Sieger), fabian.bernhard@gmx.de (F. Bernhard), urs.frey@unisg.ch (U. Frey).

1 These two authors contributed equally to this manuscript.

2 Tel.: +491733738 835 .

3 Tel.: +41712247100.
}

(Barnett \& Kellermanns, 2006; Chrisman, Chua, \& Litz, 2003; Chua, Chrisman, \& Sharma, 2003). As a consequence, justice perceptions of non-family employees in family firms have received increasing scholarly attention in recent years (cp. Barnett \& Kellermanns, 2006; Lubatkin, Ling, \& Schulze, 2007). However, the amount of existing research in that context is still regarded as insufficient (Carsrud, 2006), because it is not yet fully understood how exactly justice perceptions weave their way into favorable work attitudes. Even though scholars have intensively tried to explain this mechanism, for example by applying social exchange theory (e.g., Masterson, Lewis, Goldman, \& Taylor, 2000; Tekleab, Takeuchi, \& Taylor, 2005), Choi and Chen (2007) point out that "there is still very limited knowledge of any mechanism through which they are connected" (p. 688).

We address this gap by empirically investigating justice perceptions of non-family employees, explicitly focusing on the mechanism how they lead to affective commitment and job satisfaction. We introduce the concept of psychological ownership as a factor that connects non-family employees' justice perceptions and their work attitudes. Psychological ownership is defined as "the state in which individuals feel as though the target of ownership or a piece of that target is 'theirs"' (Pierce, Kostova, \& Dirks, 2003, p. 86). This approach is promising as formal equity ownership among non-family employees is uncommon due to the dominant wish of many families to control legal ownership across 
generations (Chua, Chrisman, \& Sharma, 1999; Gomez-Mejia, Haynes, Nunez-Nickel, Jacobson, \& Moyano-Fuentes, 2007). Feelings of ownership, however, can exist without formal ownership, and can have similar effects as intended by formal ownership (Pierce et al., 2003). Thus, ownership feelings are of special relevance for family firms. Moreover, psychological ownership seems to fit well into the context of justice perceptions and positive work outcomes. This is because on the one hand, recent initial findings indicate that there may exist a link between justice perceptions and psychological ownership (Chi \& Han, 2008). On the other hand, scholars have established positive relationships between psychological ownership and both affective commitment (Bernhard \& O'Driscoll, 2011; Mayhew, Ashkanasy, Bramble, \& Gardner, 2007; O’Driscoll, Pierce, \& Coghlan, 2006) and job satisfaction (Avey, Avolio, Crossley, \& Luthans, 2009; Van Dyne \& Pierce, 2004). However, to date, these fragmented insights have not yet been integrated, and they have not been applied in the family firm context either.

Hence, we hypothesize that psychological ownership mediates the relationships between two dimensions of organizational justice perceptions (distributive and procedural) and two common work attitudes (affective commitment and job satisfaction). We test the hypotheses on a random sample of 310 non-family employees from family firms based in Germany and Germanspeaking Switzerland. The findings based on mediation analysis constitute valuable contributions to family business research, organizational justice and psychological ownership literature, as well as to practice.

The paper is structured as follows. First, we introduce the theoretical foundations of the main concepts of this study. Second, we theoretically derive our hypotheses. Third, we illustrate the sample as well as the methods used. Fourth, we present the empirical findings. Fifth, we enter into a discussion of the results, contributions, and limitations of the study, and suggest avenues for future research. We then offer our final conclusions.

\section{Theoretical foundations}

\subsection{Organizational justice}

Due to the interaction between the family and the business system, family firms constitute a special environment for nonfamily employees to work (cp. Beehr, Drexler, \& Faulkner, 1997; Habbershon, Williams, \& MacMillan, 2003; Lansberg, 1983). They face the unique situation that they are part of the business but not part of the family system (Mitchell, Morse, \& Sharma, 2003). This situation entails unique effects on non-family employees' justice perceptions (Barnett \& Kellermanns, 2006).

Examples for potential family business specific peculiarities that might lead to perceptions of injustice among non-family employees are nepotism (Padgett \& Morris, 2005), authoritarian leadership style (Tagiuri \& Davis, 1992), human resource practices generally biased against non-family members (Barnett \& Kellermanns, 2006; Lubatkin et al., 2007; Schulze et al., 2001), ingroupoutgroup perceptions of non-family employees (Barnett \& Kellermanns, 2006), founder-centric cultures (Schein, 1983), and lack of delegation (cp. Kelly et al., 2000). In addition, when the owning family uses its power and authority to serve family rather than business interests, for instance by seeking perquisites for private consumption (Davis, Allen, \& Hayes, 2010), this behavior can give rise to non-owners' perceptions of injustice. Even though perceptions of injustice among non-family employees may not occur in all family firms in general (cp. Barnett \& Kellermanns, 2006), family firms seem to be particularly susceptible to factors leading to these perceptions. For that reason, understanding nonfamily employees' justice perceptions and how they impact pro- organizational outcomes on the individual level is a topic of essential relevance to family firms.

In recent years, a few conceptual works on justice perceptions in family firms have emerged. Barnett and Kellermanns (2006) theorized how the degree of family involvement may influence non-family employees' justice perceptions through fair or unfair human resource practices. Lubatkin et al. (2007) drew on organizational justice literature to explain agency costs in family firms. However, empirical research on non-family employees' justice perceptions is regarded as scarce (Barnett \& Kellermanns, 2006; Carsrud, 2006).

In contrast, organizational behavior literature has intensively investigated organizational justice (cp. Colquitt et al., 2001; Cropanzano, Byrne, Bobocel, \& Rupp, 2001). It is concerned with employees' subjective fairness perceptions in their employment relationship (Byrne \& Cropanzano, 2001; Greenberg, 1990). While four dimensions of organizational justice have been established, scholars agree that employees mainly draw on distributive and procedural justice perceptions when deciding how to react to the overall organization, whereas interpersonal and informational justice perceptions seem to be more relevant when referring to authority figures such as supervisors (cp. Bies \& Moag, 1986; Colquitt et al., 2001; Walumbwa, Cropanzano, \& Hartnell, 2009). In the light of this paper's goal to investigate the link between justice perceptions and non-family employees' organization-related attitudes, we limit our considerations to distributive and procedural justice.

Distributive justice refers to the perceived fairness of outcome distributions (cp. Colquitt et al., 2001). Typical examples of organizational outcomes are salaries, benefits, or promotions (cp. Colquitt, 2001; Colquitt et al., 2001). A distribution is perceived to be just if it is consistent with chosen allocation norms (Fortin, 2008) such as the widely applied equity theory (e.g., Adams, 1965; Colquitt et al., 2001). Equity theory states that people are more concerned about the fairness of outcomes than about the absolute level of these outcomes. In family firms, non-family employees thus compare their own input/output ratio to that of other individuals within their reference frame, for example with family members that are also working in the company. If the ratios are unequal, inequity is perceived, and the distribution is regarded as unjust. Procedural justice refers to the perceived fairness of the allocation process that leads to outcomes (Colquitt et al., 2001; Walumbwa et al., 2009). Thibaut and Walker (1975) found that the ability to influence or control the allocation process is able to increase individuals' perceived fairness, even if the outcome itself cannot be influenced. Existing research has linked these two justice dimensions with affective commitment (e.g., Begley, Lee, \& Hui, 2006; Jones \& Martens, 2009; Masterson et al., 2000), job satisfaction (e.g., Jones \& Martens, 2009; Lam, Schaubroeck, \& Aryee, 2002; Masterson et al., 2000), trust in the organization (Colquitt et al., 2001; Masterson et al., 2000), and organizational citizenship behavior (Aryee, Budhwar, \& Chen, 2002; Tepper \& Taylor, 2003). Recently, Chi and Han (2008) found initial evidence for a potential link to psychological ownership.

Various scholars have given insight into the mechanism that connects justice perceptions with outcomes such as affective commitment and job satisfaction. The most widely applied perspective is social exchange theory (cp. Erdogan, Liden, \& Kraimer, 2006; Masterson et al., 2000; Tekleab et al., 2005), whereas also self-esteem (Tyler \& Blader, 2000), trust (e.g., Lind, 2001; Van den Bos, Lind, \& Wilke, 2001), and organizational identification (Carmon, Miller, Raile, \& Roers, 2010) have been investigated. Despite these efforts, Choi and Chen (2007) refer to the relationship between distributive justice and affective commitment and point out that "there is still very limited knowledge of any mechanism through which they are connected" 
(p. 688). Similarly, Aryee et al. (2002) conclude that existing social exchange research is "not without limitations" (p. 268). Judge and Colquitt (2004) state that the underlying theoretical mechanisms are "less clear" compared to the effects of justice (p. 395).

In the organizational justice literature, both distributive and procedural justice perceptions are commonly situated in the context of appraisal interviews (Colquitt et al., 2001). Correspondingly, distributive justice refers to the outcome employees receive from their work (pay and promotion) that has been agreed on in their last appraisal interview. Procedural justice, in turn, refers to the process that was applied in that interview to negotiate the abovementioned outcomes (cp. also Masterson et al., 2000). Referring to family firms, Barnett and Kellermanns (2006) argue that different family business specific factors, such as the level of family influence, affect human resource practices in terms of performance appraisal, compensation, and promotion (cp. also Lubatkin et al., 2007; Schulze et al., 2001). Thus, we believe that investigating non-family employees' justice perceptions in the appraisal interview context is appropriate.

\subsection{Psychological ownership}

Employees' ownership feelings toward the organization they work for, labeled psychological ownership, have received considerable scholarly attention in recent years (Avey et al., 2009; Pierce \& Jussila, 2009; Pierce et al., 2003). When employees perceive ownership of the organization, it becomes part of the psychological owner's identity and is felt as extension of the self (Belk, 1988; Dittmar, 1992). In general, psychological ownership may exist independently of formal ownership (Pierce, Kostova, \& Dirks, 2001). Pierce et al. $(2003,2001)$ argue that psychological ownership can satisfy three underlying human motives. First, it can nurture feelings of efficacy, since "to have" is the ultimate form of control, whereby being in control leads to the perception that one "is the cause" and that one has altered or is able to alter the circumstances (Beggan, 1992). Second, ownership feelings help people define themselves, express their self-identity to others and maintain the continuity of the self. As such, possessions or what is perceived to be mine can have an identity forging and maintaining function (Kamptner, 1989; Price, Arnould, \& Folkman Curasi, 2000). Finally, having a place, and hence the need for territoriality and security may also be nurtured by ownership feelings (Porteous, 1976). Furthermore, Pierce et al. $(2001,2003)$ conceptualize three potentially interrelating routes that lead to psychological ownership: intimately knowing the target of ownership feelings, having control over it, and investing oneself into it. So far, only the route of control has been empirically validated (Pierce, O'Driscoll, \& Coghlan, 2004). Research still has to address "the conditions in organizations, work groups and individuals that enhance psychological ownership" (Avey et al., 2009, p. 186).

On the outcome side, numerous positive effects of psychological ownership among employees have been validated, such as affective commitment (e.g., Avey et al., 2009; Mayhew et al., 2007; Van Dyne \& Pierce, 2004), job satisfaction (Avey et al., 2009; Pierce, Van Dyne, \& Cummings, 1992; Van Dyne \& Pierce, 2004), organizational citizenship behavior (Avey et al., 2009), and organization-based self-esteem (Van Dyne \& Pierce, 2004).

Psychological ownership is a distinct concept because of the sense of possession as conceptual core (cp. Pierce et al., 2001; Van Dyne \& Pierce, 2004). Psychological ownership asks, "How much do I feel this organization is mine" (Van Dyne \& Pierce, 2004, p. 443 ); organizational commitment asks, "Why should I maintain my membership in this organization" (cp. Meyer \& Allen, 1997; Van Dyne \& Pierce, 2004); organizational identification asks, "Who am I" (Dutton, Dukerich, \& Harquail, 1994); and job involvement asks, "How important is the job and job performance to my selfimage?" (Lawler \& Hall, 1970).

Only recently, scholars have begun investigating psychological ownership in the family business context (e.g., Bernhard \& O'Driscoll, 2011; Bernhard \& Sieger, 2009; Sieger, 2010). This seems promising, as employee stock ownership plans, which are commonly used to foster employees' favorable work attitudes and behaviors, oppose the dominant wish of many families to control legal ownership across generations (Chua et al., 1999; GomezMejia et al., 2007). Psychological ownership, in contrast, can exist in the absence of formal ownership, while potentially leading to similar effects. For the actual evolvement of ownership feelings, family firms may constitute a unique context. For instance, when the family business is closely controlled by the family, non-family employees might perceive a low level of own personal control over the business, one of the main routes to psychological ownership. In addition, ingroup-outgroup perceptions (cp. Barnett \& Kellermanns, 2006) might bring non-family employees to perceive themselves as being outside the group of owners, which might impede the evolvement of ownership feelings. In contrast, when non-family employees perceive to be part of the family, for example through very long tenure, this might foster ownership feelings. As outlined in the following, also perceptions of justice or injustice may affect non-family employees' ownership feelings.

\subsection{Affective commitment and job satisfaction}

Affective commitment and job satisfaction are described as "the two most commonly researched employee attitudes" (Van Dyne \& Pierce, 2004, p. 440). Meyer and Allen (1991) differentiate between affective, normative, and continuance commitment. Affective commitment is regarded as the most widely studied form (Lavelle et al., 2009; Meyer et al., 2002; Pierce et al., 2003). It is defined as "affective or emotional attachment to the organization such that the strongly committed individual identifies with, is involved in, and enjoys membership in the organization" (Allen \& Meyer, 1990, p. 2). In the context of family firms, affective commitment is of special relevance. For instance, family firms are characterized by long term orientation (Chua et al., 1999; Klein, Astrachan, \& Smyrnios, 2005). In addition, they have a stronger tendency to keep their employees even in times of economic crises (Lee, 2006). Altogether, this is likely to lead to increased trust, feelings of job security, and a higher level of affective commitment (Astrachan \& Kolenko, 1994; Le Breton-Miller \& Miller, 2006). Fostering nonfamily employees' affective commitment is essential as family firms may have disadvantages in attracting new hires and thus have to rely more on existing employees (Michael-Tsabari, Lavee, \& Hareli, 2008). Moreover, recent findings indicate that non-family employees' affective commitment is positively related to the profitability and survival of family firms (Vallejo, 2009). Thus, it is surprising that there is relatively little literature specifically dedicated to the affective commitment of non-family employees in family businesses (cp. Bird, Welsch, Astrachan, \& Pistrui, 2002; Dyer, 2003).

Job satisfaction is another important work attitude (cp. Heller \& Watson, 2005; Ilies, Wilson, \& Wagner, 2009; Van Dyne \& Pierce, 2004). It has been commonly defined as an attitudinal evaluative judgment of one's job or job experiences (Ilies et al., 2009). It basically asks, 'How do I evaluate my job?' (Van Dyne \& Pierce, 2004, p. 444). Family business literature has mainly investigated job satisfaction with regard to family members. In that context, numerous scholars have concentrated on the relationships between work and family domains and their effects on job satisfaction (cp. Edwards \& Rothbard, 2000; Kossek \& Ozeki, 1998). Investigated factors in that context are work-family conflict, 
family cohesion and family adaptability (Boles, 1996; Lee, 2006). While Lumpkin, Martin, and Vaughn (2008) pointed out that the family orientation of non-family employees might have an effect on their job satisfaction, there are very few empirical studies explicitly examining non-family employees' job satisfaction (for instance, see Beehr et al., 1997).

\section{Hypotheses}

\subsection{Organizational justice dimensions and psychological ownership}

\subsubsection{Distributive justice and psychological ownership}

Equity theory posits that employees perceive justice when they receive resource allocations that commensurate with their contribution to the firm (Adams, 1965). Family firms, however, may be prone to violating that allocation norm. For instance, the concept of altruism implies that the welfare of the parent is positively linked to that of his or her children (Schulze, Lubatkin, \& Dino, 2003; Schulze et al., 2001). As a consequence, parental altruism can bias the family's perception about the performance of family members, and business families are incentivized to offer perquisites, promotional opportunities and salaries to family employees regardless of their individual contribution to the firm (Lubatkin et al., 2007). An example is appointing a family member to a specific position even though a non-family employee would be better qualified (Gersick, Davis, Hampton, \& Lansberg, 1997). When the norm of merit (cp. Lansberg, 1983) is replaced or weakened through altruism or general favoritism of family members (Lubatkin et al., 2007; Schulze et al., 2001), this is likely to lead to perceptions of distributive injustice by non-family employees. Even though non-family employees might expect or even accept a certain extent of preferential treatment of family members (Gersick et al., 1997), perceptions of injustice may arise as soon as the "non-family employees' zone of indifference" is left (Lubatkin et al., 2007, p. 965). As mentioned previously, however, even though family firms are particularly vulnerable to the violation of distributive justice rules, this does not necessarily have to be the case.

The level of justice that non-family employees perceive with regard to outcome distributions such as pay and promotion has important effects on their relationship with the organization. Accountability considerations imply that individuals identify the party that is responsible for justice or injustice, which in turn affects their attitudes toward that party (cp. Folger \& Cropanzano, 1998). Pay policies, compensation and promotion schemes in firms are mostly set by the firm itself (see also Walumbwa et al., 2009). Consequently, when non-family employees perceive pay and promotion to be unjust, they are also likely to perceive the family firm as unjust. In contrast, if these outcomes are perceived as just, this applies to the family firm as well. This, in turn, supports a more favorable relationship between the employee and the organization (cp. Colquitt et al., 2001; Fortin, 2008). With increased justice, a just family firm appears attractive to non-family employees. Favorable judgments are related to possessive feelings (Beggan, 1992), and Pierce et al. (2003) state that "attributes like attractiveness [...] render the target more or less subject to psychological ownership" (p. 94).

Also resource investment considerations may play a role. Janssen, Lam, and Huang (2009) propose that employees who perceive their resource investments to be fairly compensated by the organization will be motivated and encouraged to increasingly invest their personal resources. These personal resources can be intelligence, experience, training, skill, time, energy, and cognitive and emotional labor (Janssen et al., 2009). A high level of distributive justice thus fosters the employees' resource investment. In a similar vein, Loi, Hang-yue, and Foley (2006) argue that when employees perceive distributive justice in an economic exchange relationship, they are motivated to repay and increase their self-investment in the organization. At the same time, the investment of "time, ideas, skills and physical, psychological, and intellectual energies" (Pierce et al., 2001, p. 302) has been proposed to be one of the three main routes leading to psychological ownership (Pierce et al., 2001, 2003).

Summing up, there is good reason to believe that distributive justice perceptions render the family firm into a more attractive object to be psychologically appropriated, and that they will also foster the investment of non-family employees' personal resources. This will ultimately strengthen non-family employees' ownership feelings toward the family business. More formally stated:

Hypothesis 1. Distributive justice perceptions of non-family employees are positively related to their psychological ownership toward the family business.

\subsubsection{Procedural justice and psychological ownership}

For procedural justice, six criteria have been established that employees normally evaluate. Just procedures are suggested to be based on accurate information, free of bias, applied consistently across people and time, have a mechanism to correct flaws, consider the opinions of several affected groups, and conform to ethical standards (Colquitt et al., 2001; Leventhal, 1980). Family firms face a higher risk of violating one or several of these rules. For instance, family firms are sometimes described to avoid establishing formal procedures, which can impede the quality and accuracy of internal information flows (Gomez-Mejia, Nunez-Nickel, \& Gutierrez, 2001; Schulze et al., 2001). Moreover, due to non-family employees' family outsider status, they have less institutional influence to suggest corrective actions and to express their opinion compared to family members (Lubatkin et al., 2007). The danger of violating the six criteria may be exacerbated for instance by founder-centric cultures (Schein, 1983) or authoritarian leadership styles (Tagiuri \& Davis, 1992). The allocation process through which outcomes such as pay and promotion are distributed is then likely to be conducted top-down, without the possibility for nonfamily employees to adequately have a voice. Even though scholars found that non-family employees regularly complain about a lack of voice with respect to family firm decision making (Van der Heyden, Blondel, \& Carlock, 2005), this might not be necessarily the case for all family firms. Rather, if the controlling family is aware of these dangers, they can take actions and implement mechanisms to avoid such situations.

The extent to which procedures applied in the context of an appraisal interview, the most commonly investigated allocation process (cp. Barnett \& Kellermanns, 2006; Colquitt et al., 2001), are affected by these factors, has a direct effect on non-employees' procedural justice perceptions and their subsequent ownership feelings for the organization. Appraisal interview procedures are likely to be developed by the organization and are only carried out by a supervisor. Drawing from the discussion about sources of justice perceptions (Malatesta \& Byrne, 1997; Masterson et al., 2000; Masterson \& Taylor, 1996) and accountability (Folger \& Cropanzano, 1998), the family firm will then be held accountable for justice or injustice (Masterson et al., 2000). Hence, non-family employees tend to consider the family firm to be just, if they perceive the procedures to be just (cp. Folger \& Cropanzano, 1998). This link can also be clarified by considering the difference between event-based and entity-based judgments. Event-based judgments refer to an individual's fairness assessment of a specific event or experience, such as an appraisal interview. Entity-based judgments, in turn, are aggregated event perceptions to form a 
summary judgment of a social entity, such as an organization (cp. Cropanzano et al., 2001). Fair procedures go along with the perception of a fair organization, which is supported by Hollensbe, Khazanchi, and Masterson (2008). Additional empirical support for a high correlation between event and entity-based judgments is provided by Konovsky and Pugh (1994). When the family firm as a whole is consequently perceived as just, it becomes a more desirable object to be psychologically appropriated (Pierce et al., 2003).

Furthermore, just procedures allow non-family employees to control, predict, and maximize the favorability of outcomes in the long term (cp. Cropanzano et al., 2001; Greenberg, 1990; Shapiro, 1993; Thibaut \& Walker, 1975). If just procedures are in place and are perceived as such, non-family employees perceive to have influence and control over the instruments and processes through which relevant job-related outcomes are determined. This can be regarded as a proxy for control over the employee's work environment and related issues in general (cp. Pierce et al., 2001). Perceived control, in turn, satisfies the human motive of efficacy and is the only empirically validated main route to psychological ownership (Pierce et al., 2004).

Summing up, just procedures in the context of an appraisal interview will make non-family employees perceive that the family firm as a whole is just, which facilitates the evolvement of ownership feelings. In addition, just procedures give non-family employees a sense of influence and control, which is one of the main antecedents to psychological ownership. Based on these considerations we offer the following hypothesis:

Hypothesis 2. Procedural justice perceptions of non-family employees are positively related to their psychological ownership toward the family business.

\subsection{The mediating effects of psychological ownership}

We propose psychological ownership of non-family employees as a mediator in the relationships between justice perceptions and favorable work outcomes due to numerous reasons. First, many studies have reported positive relationships between both distributive and procedural justice and affective commitment (e.g., Begley et al., 2006; Greenberg, 1994; Jones \& Martens, 2009; Lowe \& Vodanovich, 1995), and between both justice dimensions and job satisfaction (Jones \& Martens, 2009; e.g., Lam et al., 2002; Masterson et al., 2000). This should also hold in the context of family firms. When non-family employees perceive that they are fairly compensated and treated in the procedure to arrive at these outcomes, this is likely to have positive effects on their affective commitment to the family firm and to their job satisfaction (cp. also Kets de Vries, 1993). Second, as illustrated above, we propose a positive relationship between both distributive and procedural justice perceptions and psychological ownership of non-family employees. Third, psychological ownership has been linked to both affective commitment and job satisfaction. Feelings of ownership satisfy the basic human need for place (Porteous, 1976), and nonfamily employees thus view the family firm as a place in which to dwell (Dittmar, 1992; Furby, 1978; Pierce et al., 2001). This induces a feeling of attachment and belonging, which is the essence of affective commitment (cp. Van Dyne \& Pierce, 2004). Scholars also argue that feelings of possession enhance general satisfaction and provide a context or environment in which job satisfaction is embedded and positively influenced (Kozlowski \& Klein, 2000; Van Dyne \& Pierce, 2004). We believe that these relationships also apply to the context of non-family employees in family firms.

Based on above assertions it seems reasonable to introduce psychological ownership as a mediator between distributive justice and both affective commitment and job satisfaction, as well as between procedural justice and the same attitudinal outcomes. When family firms are able to induce perceptions of justice among their non-family employees despite potential family business specific pitfalls, this will give rise to ownership feelings, which in turn will positively affect non-family employees' affective commitment and job satisfaction. These arguments lead us to the following mediation hypotheses:

Hypothesis 3. Psychological ownership of non-family employees toward the family business mediates the relationship between their distributive justice perceptions and their affective commitment.

Hypothesis 4. Psychological ownership of non-family employees toward the family business mediates the relationship between their procedural justice perceptions and their affective commitment.

Hypothesis 5. Psychological ownership of non-family employees toward the family business mediates the relationship between their distributive justice perceptions and their job satisfaction.

Hypothesis 6. Psychological ownership of non-family employees toward the family business mediates the relationship between their procedural justice perceptions and their job satisfaction.

The theoretical model is illustrated in Fig. 1.

\section{Method}

\subsection{Sample and data collection}

The sample consists of the responses of 1024 employees of companies based in Germany and German-speaking Switzerland. In 2009, we randomly retrieved 10,750 valid email addresses of management-level employees from these countries' largest employee database. An identification-based online survey instrument prevented multiple responses. We achieved a response rate of $9.5 \%$ by using one reminder email. Research has found that a 10 $12 \%$ response rate is typical for studies that target executives in upper echelons (Geletkanycz, 1998; Koch \& McGrath, 1996) and managers in small to mid-sized firms (MacDougall \& Robinson, 1990). In addition, sending emails without prior notice generates lower response rates than other approaches (Kaplowitz, Hadlock, \& Levine, 2004). Given the circumstances, our response rate can thus be regarded as adequate. We only included fully completed questionnaires and respondents that were working in a family firm. The criteria were at least one family member in an operational position, majority of equity ownership in the family's hands, and the employees' perception that it is a family business (cp. Astrachan, Klein, \& Smyrnios, 2002; Nordqvist \& Zellweger, 2010). In addition, family members were excluded, which reduced

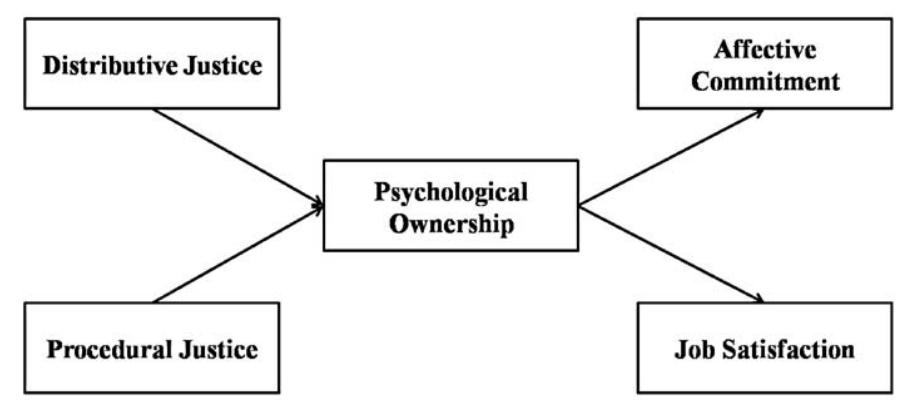

Fig. 1. Theoretical model. 
the final sample to 310 employees. $26 \%$ of them were females, with an average age of 45.25 years, and an average tenure of 12.06 years. Average company age was 81.2 years, and average company size was 847.64 employees.

\subsection{Measures}

To measure distributive and procedural justice we relied on a validated German version (Maier et al., 2007) of the widely applied measure by Colquitt (2001). Following Colquitt (2001), distributive justice referred to the outcome non-family employees receive from their work (pay and promotion) based on their last appraisal interview, and procedural justice referred to the process applied in that interview (cp. also Masterson et al., 2000). Sample items were "Does your appraisal interview outcome (e.g., salary, promotion, and raise) reflect the effort you have put into your work?" (distributive justice) and "Have you been able to express your views and feelings during your last appraisal interview?" (procedural justice). All items in the study were rated from 1 = strongly disagree to 7 = strongly agree on a seven-point Likerttype scale. We pre-tested the scale with 90 employees and found low factor loadings $(<0.6)$ for the same items as Maier et al. (2007), leading to 4 items for distributive and 5 items for procedural justice (cp. Nunnally \& Bernstein, 1994). A factor analysis confirmed this factor structure. Cronbach's alphas were 0.95 and 0.85. All items used in this study can be found in Appendix A.

For psychological ownership we relied on a seven item measure developed by Pierce et al. (1992), with further validation provided by numerous scholars (e.g., Mayhew et al., 2007; O'Driscoll et al., 2006; Pierce et al., 2004). Sample items included "I feel a very high degree of personal ownership for this organization" and "This is MY organization". After translating the scale into German, two independent bilingual experts who did not know the original scale retranslated it into English. Together with a native English speaker we compared the English version of the scale with our translation. No major differences were found. Cronbach's alpha was 0.89 . For affective commitment we relied on the scale by Allen and Meyer (1990) and its validated German version (Felfe, Six, Schmook, \& Knorz, 2004). We used the six items that exhibited the highest factor loadings ( $>0.6$ ) in our pre-test. Sample items were "I would be very happy to spend the rest of my career with this organization" or "This organization has a great deal of personal meaning for me". Cronbach's alpha was 0.93 . We used a three item measure inspired by Van Dyne and Pierce (2004), Mayhew et al. (2007), and Zhou, Li, Zhou, and Su (2008) to measure job satisfaction, whereas the same translation procedure as described above was enacted. Sample items were "I like the things that I do at work" and "In general, I am very satisfied with my job". Cronbach's alpha was 0.81 .

We used several control variables. As conceptualizations of ownership can differ between countries due to varying legal arrangements and social programs (Rousseau \& Shperling, 2003), we included dummy variables for Germany and Switzerland. Moreover, the competitive environment may impact firm behavior (Antoncic \& Hisrich, 2001; Porter, 1985), and consequently employees' feelings and attitudes. Thus, we added dummy variables for industry and service sectors. We also controlled employees' age (McFarlin \& Sweeney, 1992), gender (Lee, Pillutla, \& Law, 2000), tenure (Meyer et al., 2002), hierarchy level (Begley et al., 2006), and stock ownership (Daily, Dalton, \& Rajagopalan, 2003; Van Dyne \& Pierce, 2004). Other controls were firm age and size, whereas the latter was measured by the number of employees (cp. Choi \& Chen, 2007; Wallace, 1995). As it was not normally distributed, we transformed it using the natural logarithm. Furthermore, we included the company's current performance, as the study variables might be affected when the company is perceived as successful and thus attractive (cp. Pierce et al., 2003). We adapted a measure by Eddleston and Kellermanns (2007), including three items pertaining to the company's development of sales, market share, and profits in comparison to its competitors. Cronbach's alpha was 0.91 .

\section{Analysis}

To explore the possibility of non-response bias, we compared early and late respondents using ANOVA, as late respondents are more similar to non-respondents than early respondents (Chrisman, Chua, \& Litz, 2004; Oppenheim, 1966). No significant differences in the mean scores of the variables were found. To address the potential of common method bias we used Harman's one factor test (1967) as suggested by Podsakoff and Organ (1986). Following Podsakoff, MacKenzie, Lee, and Podsakoff (2003), we entered all our study variables into a factor analysis, extracting a 11 -factor solution, accounting for $74.32 \%$ of total variance. The first factor explained $25.23 \%$ of variance, providing initial evidence that common method bias was not a major problem because no single factor accounted for the majority of variance. As an additional precaution and to assess the validity and distinctiveness of our measures, we conducted a confirmatory factor analysis (Podsakoff et al., 2003). Specifically, we compared the fit of a five-factor structure with our main variables to that of a one-factor structure. The five-factor structure fits the data significantly better (difference in $\chi^{2}=3180.922$, $\mathrm{df}=10, p<0.001$ ). This indicates that our measures were not only theoretically but also empirically distinguishable, and further mitigate common method bias concerns (Podsakoff et al., 2003). To deal with potential multicollinearity we centered the variables (cp. Cronbach, 1987) and found that the Variance Inflation Factor did not exceed 2.357, and the condition index did not exceed 13.752, suggesting that multicollinearity is not a concern (Hair, Black, Babin, Anderson, \& Tatham, 2006). While our statistical tests mitigate common method bias and multicollinearity concerns, we have to note that the correlation between distributive and procedural justice is high. This is regrettable, but seems to be a common problem in organizational justice research (cp. Choi \& Chen, 2007; Erdogan et al., 2006; Judge \& Colquitt, 2004; Spell \& Arnold, 2007; Walumbwa et al., 2009). To investigate the mediating effects we followed Baron and Kenny (1986) and tested the mediation effects' significance with the Sobel test (cp. MacKinnon, Lockwood, Hoffman, West, \& Sheets, 2002).

\section{Results}

Means, standard deviations, and Pearson's correlations are reported in Table 1.

Our hypotheses are tested in Table $2^{4}$. Hypotheses 1 and 2 are investigated in model 1 . Adding distributive and procedural justice significantly increases explained variance over and above the control model (adjusted $R^{2}=0.177$ ). We find a significant and positive relationship between distributive justice and psychological ownership $(r=0.148, p<0.05)$, which confirms Hypothesis 1 . However, the relationship between procedural justice and psychological ownership is not significant, which rejects Hypothesis 2.

For mediation to occur, three conditions must be met (Baron \& Kenny, 1986). First, the independent variable must affect the mediator. This applies only for distributive justice (model 1). Second, the independent variable must affect the dependent variable. In model 2 , we find a significant relationship between distributive justice and affective commitment $(r=0.212, p<0.01)$, but not for procedural justice and affective commitment, while the

\footnotetext{
${ }^{4}$ To improve readability we did not report the different control models.
} 
Table 1

Means, standard deviations (S.D.), and Pearson's correlations.

\begin{tabular}{|c|c|c|c|c|c|c|c|c|c|c|c|}
\hline & & Mean & S.D. & 1 & 2 & 3 & 4 & 5 & 6 & 7 & 8 \\
\hline 1 & Switzerland & 0.52 & 0.5 & 1 & & & & & & & \\
\hline 2 & Germany & 0.32 & 0.47 & $-0.723^{* *}$ & 1 & & & & & & \\
\hline 3 & Industry & 0.33 & 0.47 & $0.252^{* *}$ & $-0.171^{* *}$ & 1 & & & & & \\
\hline 4 & Service & 0.91 & 0.28 & $-0.184^{* *}$ & $0.166^{* *}$ & $-0.445^{* *}$ & 1 & & & & \\
\hline 5 & Employee age & 45.25 & 8.67 & $0.110^{*}$ & -0.027 & 0.039 & -0.024 & 1 & & & \\
\hline 6 & Gender & 1.27 & 0.45 & -0.018 & 0.036 & 0.051 & -0.040 & $-0.231^{* *}$ & 1 & & \\
\hline 7 & Tenure & 12.06 & 8.84 & -0.056 & $0.111^{*}$ & 0.026 & 0.003 & $0.486^{* *}$ & $-0.127^{*}$ & 1 & \\
\hline 8 & Hierarchy level & 5.08 & 0.94 & $0.145^{* *}$ & -0.024 & 0.075 & -0.031 & $0.286^{* *}$ & $-0.409^{*}$ & 0.091 & 1 \\
\hline 9 & Share ownership & 1.93 & 0.26 & $-0.108^{*}$ & 0.093 & -0.064 & $0.132^{*}$ & 0.034 & $0.018^{*}$ & -0.048 & -0.076 \\
\hline 10 & Company age & 81.20 & 59.37 & $0.209^{* * *}$ & $-0.160^{* *}$ & 0.016 & -0.038 & 0.071 & -0.011 & $0.125^{*}$ & 0.035 \\
\hline 11 & Company size (ln) & 5.785 & 1.13 & -0.015 & -0.042 & 0.068 & $-0.109^{*}$ & -0.028 & -0.085 & 0.041 & -0.012 \\
\hline 12 & Current performance & 4.70 & 0.87 & $0.173^{* *}$ & $-0.108^{*}$ & $0.166^{* *}$ & $-0.140^{*}$ & 0.031 & -0.035 & -0.033 & 0.095 \\
\hline 13 & Distributive justice & 4.91 & 1.23 & $0.149^{* * *}$ & $-0.110^{*}$ & $0.141^{*}$ & -0.069 & 0.026 & 0.072 & -0.032 & $0.134^{*}$ \\
\hline 14 & Procedural justice & 5.17 & 1.01 & $0.140^{* *}$ & $-0.202^{* *}$ & $0.121^{*}$ & -0.074 & -0.028 & 0.004 & -0.076 & 0.089 \\
\hline 15 & Psychological ownership & 4.44 & 1.29 & 0.043 & -0.027 & $0.155^{* *}$ & -0.074 & $0.194^{* *}$ & $-0.203^{* * *}$ & $0.141^{* *}$ & $0.356^{* *}$ \\
\hline 16 & Affective commitment & 5.39 & 1.06 & 0.044 & 0.017 & 0.098 & -0.071 & $0.131^{*}$ & -0.062 & $0.185^{* *}$ & $0.235^{* *}$ \\
\hline \multirow[t]{2}{*}{17} & Job satisfaction & 5.81 & 0.71 & $0.140^{* *}$ & -0.094 & $0.185^{* *}$ & -0.068 & 0.013 & -0.018 & 0.027 & 0.082 \\
\hline & & Mean & S.D. & 9 & 10 & 11 & 12 & 13 & 14 & 15 & 16 \\
\hline 1 & Switzerland & 0.52 & 0.5 & & & & & & & & \\
\hline 2 & Germany & 0.32 & 0.47 & & & & & & & & \\
\hline 3 & Industry & 0.33 & 0.47 & & & & & & & & \\
\hline 4 & Service & 0.91 & 0.28 & & & & & & & & \\
\hline 5 & Employee age & 45.25 & 8.67 & & & & & & & & \\
\hline 6 & Gender & 1.27 & 0.45 & & & & & & & & \\
\hline 7 & Tenure & 12.06 & 8.84 & & & & & & & & \\
\hline 8 & Hierarchy level & 5.08 & 0.94 & & & & & & & & \\
\hline 9 & Share ownership & 1.93 & 0.26 & 1 & & & & & & & \\
\hline 10 & Company age & 81.20 & 59.37 & -0.057 & 1 & & & & & & \\
\hline 11 & Company size (ln) & 5.785 & 1.13 & -0.035 & $0.167^{* *}$ & 1 & & & & & \\
\hline 12 & Current performance & 4.70 & 0.87 & -0.106 & -0.006 & $0.217^{* *}$ & 1 & & & & \\
\hline 13 & Distributive justice & 4.91 & 1.23 & -0.070 & -0.019 & 0.094 & $0.239^{* *}$ & 1 & & & \\
\hline 14 & Procedural justice & 5.17 & 1.01 & -0.060 & -0.049 & $0.124^{*}$ & $0.265^{* *}$ & $0.682^{* *}$ & 1 & & \\
\hline 15 & Psychological ownership & 4.44 & 1.29 & -0.100 & 0.024 & 0.010 & $0.174^{* *}$ & $0.222^{* *}$ & $0.173^{* *}$ & 1 & \\
\hline 16 & Affective commitment & 5.39 & 1.06 & -0.093 & -0.085 & -0.036 & $0.257^{* *}$ & $0.301^{* *}$ & $0.237^{* *}$ & $0.418^{* *}$ & 1 \\
\hline 17 & Job satisfaction & 5.81 & 0.71 & -0.028 & -0.043 & 0.020 & $0.258^{* *}$ & $0.434^{* * *}$ & $0.360^{* *}$ & $0.275^{* *}$ & $0.545^{* *}$ \\
\hline
\end{tabular}

$N=310$.

${ }^{*} p<0.05$.

Table 2

Results of regression analyses.

\begin{tabular}{|c|c|c|c|c|c|}
\hline Variables & Model 1 & Model 2 & Model 3 & Model 4 & Model 5 \\
\hline Dependent variable & Psychological ownership & Affective commitment & Affective commitment & Job satisfaction & Job satisfaction \\
\hline \multicolumn{6}{|l|}{ Control variables } \\
\hline Switzerland & -0.133 & -0.034 & 0.005 & 0.052 & 0.078 \\
\hline Germany & -0.081 & -0.012 & 0.012 & 0.005 & 0.020 \\
\hline Industry & 0.115 & 0.039 & 0.005 & $0.119^{*}$ & 0.096 \\
\hline Service & 0.006 & -0.015 & -0.017 & 0.036 & 0.034 \\
\hline Employee Age & 0.061 & -0.059 & -0.077 & -0.041 & -0.053 \\
\hline Gender & -0.096 & 0.029 & 0.058 & 0.015 & 0.034 \\
\hline Tenure & 0.079 & $0.252^{* * *}$ & $0.228^{* * *}$ & 0.078 & 0.063 \\
\hline Hierarchy level & $0.255^{* * *}$ & $0.206^{* *}$ & $0.130^{*}$ & 0.019 & -0.032 \\
\hline Share ownership & -0.065 & 0.000 & 0.019 & 0.035 & 0.047 \\
\hline Company age & 0.035 & -0.040 & -0.050 & -0.013 & -0.020 \\
\hline Company size $(\ln )$ & -0.031 & $-0.125^{*}$ & $-0.115^{*}$ & -0.099 & -0.093 \\
\hline Current perf. & 0.102 & $0.230^{* * *}$ & $0.200^{* * *}$ & $0.164^{* *}$ & $0.144^{* *}$ \\
\hline \multicolumn{6}{|c|}{ Independent variables/mediator } \\
\hline Distributive justice & $0.148^{*}$ & $0.212^{* *}$ & $0.168^{*}$ & $0.313^{* * *}$ & $0.284^{* * *}$ \\
\hline Procedural justice & 0.031 & 0.011 & 0.001 & 0.113 & 0.107 \\
\hline Psychological ownership & & & $0.298^{* * *}$ & & $0.197^{* * *}$ \\
\hline Adjusted $R^{2}$ & 0.177 & 0.209 & 0.280 & 0.228 & 0.257 \\
\hline F-Statistics & $5.758^{* * *}$ & $6.842^{* * *}$ & $9.009^{* * *}$ & $7.509^{* * *}$ & $8.133^{* * *}$ \\
\hline Delta $R^{2}$ & $0.026^{* *}$ & $0.042^{* * *}$ & $0.070^{* * *}$ & $0.138^{* * *}$ & $0.031^{* * *}$ \\
\hline
\end{tabular}

Sobel test (for distributive justice and affective commitment): $z=3.687, p<0.001$. Sobel test (for distributive justice and job satisfaction): $z=2.846, p<0.01$. $N=310$. ${ }^{*} p<0.05$.

$p<0.01$

$p<0.001$ 
explained variance of the model increases significantly (adjusted $R^{2}=0.209$ ). Third, when investigating the effects of the independent variable and the mediator on the dependent variable simultaneously, the effect of the mediator has to be significant, and the effect of the dependent variable has to be weaker than in condition 2 (cp. Baron \& Kenny, 1986). Model 3 shows that psychological ownership is significantly related to affective commitment $(r=0.298, p<0.001)$, while the effect of distributive justice is weaker but significant $(r=0.168, p<0.05)$. Adding psychological ownership significantly increases explained variance over and above model 2 (adjusted $R^{2}=0.280$ ). This indicates partial mediation and supports hypothesis 3 . The Sobel test confirms this finding $(z=3.687, p<0.001)$. Hypothesis 4 , however, has to be rejected. Referring to job satisfaction, adding both dimensions of justice perceptions increases explained variance of model 4 over and above the control model (adjusted $R^{2}=0.228$ ). Model 4 shows that distributive justice is significantly related to job satisfaction $(r=0.313, p<0.001)$, while procedural justice is not. When psychological ownership is added in model 5 , which significantly increases explained variance compared to model 4 (adjusted $R^{2}=0.257$ ), psychological ownership is significant $(r=0.197, p<0.001)$, whereas the effect of distributive justice is weaker but significant $(r=0.284, p<0.001)$. The Sobel test confirms this effect $(z=2.846, p<0.01)$, lending support to Hypothesis 5, whereas Hypothesis 6 has to be rejected.

\section{Discussion}

Our study set out to investigate non-family employees' justice perceptions and how they are connected with pro-organizational outcomes through psychological ownership. The gained insights constitute a number of valuable contributions. First, we add to family business literature. Research on justice perceptions of nonfamily employees is scarce, and our study represents one of the very few empirical studies (cp. Barnett \& Kellermanns, 2006; Carsrud, 2006). By drawing a fine-grained picture of how justice perceptions of non-family employees weave their way into relevant outcomes, we increase the understanding of how family firms can foster their employees' value-creating attitudes (Barnett \& Kellermanns, 2006; Chrisman et al., 2003; Chua et al., 2003). We are the first to both theoretically and empirically link non-family employees' justice perceptions and ownership feelings in the family firm context. Moreover, we are able to validate psychological ownership as a mediator between distributive justice and both affective commitment and job satisfaction. Compensating non-family employees in a just manner despite potential family business-specific pitfalls can induce ownership feelings toward the family firm, and ultimately positive attitudinal outcomes, which offers a new explanation how the mechanism connecting justice perceptions and favorable outcomes might look like. In contrast, our finding that a just process in the context of appraisal interviews is not able to trigger ownership feelings indicates that non-family employees rather regard the supervisor responsible for justice, and that this assessment is not transferred to the family business as a whole. Furthermore, we elaborated that psychological ownership can be especially interesting for family firms that avoid sharing formal ownership with nonfamily members. Potentially inducing similar effects as traditional equity ownership plans, it avoids the inherent disadvantages of these programs. Our empirical results confirm the unique potential of psychological ownership in the family firm context. Second, we contribute to the field of organizational justice. On the one hand, we offer detailed theoretical reasoning and validate the relationship between distributive justice and psychological ownership. On the other hand, psychological ownership offers a new perspective in understanding the mechanism that connects justice perceptions and organization-related outcomes, which complements existing approaches (e.g., Masterson et al., 2000; Tyler \& Blader, 2000; Van den Bos et al., 2001) and addresses an acknowledged research gap (Choi \& Chen, 2007). Moreover, our finding that procedural justice perceptions do not affect non-employees' attitudes toward the organization as a whole might challenge traditional assumptions of organizational justice scholars (e.g., Bies \& Moag, 1986; Walumbwa et al., 2009). Third, we add to psychological ownership literature. In general, our study joins the young stream of research that investigates psychological ownership in a family firm context. We are the first to validate psychological ownership as a mediator between justice perceptions and both affective commitment and job satisfaction, which adds to knowledge on psychological ownership in general (Pierce et al., 2003). Establishing a link between distributive justice perceptions and psychological ownership extends the initial findings of Chi and Han (2008) and addresses the call of Avey et al. (2009) to further investigate psychological ownership's antecedents (cp. also Pierce et al., 2004). Fourth, our insights are of value for family business practitioners. We encourage them to pay close attention to the distribution of salaries and promotions. Related perceptions of injustice can impede the evolvement of ownership feelings, and ultimately affective commitment and job satisfaction. Family business practitioners should thus be aware of the dangers of altruism and favoritism towards family members, and should try to allocate salaries and promotions strictly depending on the contribution that each individual adds to the family firm. In general, distributive justice seems to be more essential than procedural justice when fostering non-family employees' value-creating attitudes. In addition, due to the positive effects of psychological ownership, we encourage family business practitioners to take actions beyond fostering distributive justice in order to enhance ownership feelings, such as for instance increasing perceptions of control.

\section{Limitations}

First, we have to address the issue of causality in this study. As the study is based on cross-sectional data, we cannot derive solid claims about the direction of our effects. It could be argued that when nonfamily employees exhibit ownership feelings toward the family firm they are working for, this could make them evaluate the distribution of outcomes as well as the corresponding process in a more favorable manner. However, even though we cannot substantiate the direction of the effects empirically, previous theoretical considerations lend support to the presented model (Chi \& Han, 2008; Pierce et al., 2003; Pierce, Rubenfeld, \& Morgan, 1991). Another limitation is that all variables were measured by the responses of a single source. However, due to theoretical reasons we have to rely on non-family employees' subjective justice perceptions, ownership feelings, and their individual affective commitment and job satisfaction. Thus, this measurement approach can be justified. In addition, several tests mitigate common method bias concerns. Lastly, respondents were all working in firms based in Germany or German-speaking Switzerland, which could lead to a cultural bias.

\section{Future research}

Our research opens up several avenues for future research. Most importantly, we strongly encourage other researchers to further investigate the role of psychological ownership in the relationship between justice perceptions and attitudinal outcomes of non-family employees. Here, the influence of family business specific variables could be addressed as a next step, such as level of family involvement (Barnett \& Kellermanns, 2006), family ownership, family conflicts (Boles, 1996), governance systems, or image and reputation. In addition, we only found partial mediating effects for psychological ownership, which speaks for the existence of other mechanisms and 
processes in the distributive justice - affective commitment and distributive justice - job satisfaction relationships. We therefore encourage future studies to develop comprehensive models addressing the specific role and weight of psychological ownership compared with other suggested mediators such as self-esteem (Tyler \& Blader, 2000), trust (e.g., Lind, 2001; Van den Bos et al., 2001), and organizational identification (Carmon et al., 2010). Furthermore, psychological ownership as a mediator could be applied to other outcomes such as organizational citizenship behavior or company performance. Exploring causality effects with longitudinal data and validating our results in other cultural contexts may also be fruitful avenues of future research. For psychological ownership scholars it may be worthwhile to examine the link between different justice dimensions and psychological ownership in more detail. For example, a mediating effect of employees' perceived control in these relationships could be explicitly studied (cp. Pierce et al., 2003).

\section{Conclusion}

Addressing the important issue of non-family employees' justice perceptions and how they lead to pro-organizational outcomes, we successfully validate psychological ownership as an alternative mediator in the relationship between organizational justice perceptions and affective commitment as well as job satisfaction. Our findings constitute valuable additions to family business research, organizational justice and psychological ownership literature, and to practice.

\section{Appendix A. Scale items, factor loadings, and reliabilities}

\begin{tabular}{lll}
\hline Construct & Item & $\alpha$ \\
\hline Distributive justice & The following items refer to your outcome (e.g., salary, promotion, and raise) of your last & $\mathrm{FL}$
\end{tabular}

Distributive justice

The following items refer to your outcome (e.g., salary, promotion, and raise) of your last 0.95 appraisal interview. To what extent:

Does your appraisal interview outcome (e.g., salary, promotion, and raise) reflect the effort you have put into your work?

Is your outcome of the appraisal interview (e.g., salary, promotion, and raise) appropriate for the work you have completed?

Does your appraisal interview outcome (e.g., salary, promotion, and raise) reflect what you have contributed to the organization?

Is your outcome of the appraisal interview (e.g., salary, promotion, and raise) justified, given your performance?

Procedural justice $\quad$ The following items refer to the procedures used to arrive at your outcomes at your last appraisal interview. To what extent:

Have you been able to express your views and feelings during the appraisal interview? Have you had influence over the outcome (e.g., salary, promotion, and raise) arrived at by the appraisal interview?

Have the appraisal interviews been applied consistently?

Have the appraisal interview been based on accurate information? organization that you work for. Indicate the degree to which you personally agree or disagree with the following statements.

This is MY organization.

This is OUR company. 


\section{References}

Adams, J. S. (1965). Inequity in social exchange. In Berkowitz, L. (Ed.). Advances in experimental social psychology (Vol. 2, pp. 267-299). New York: Academic Press.

Allen, N. J., \& Meyer, J. P. (1990). The measurement and antecedents of affective, continuance and normative commitment to the organization. Journal of Occupational Psychology, 63(1), 1-18.

Antoncic, B, \& Hisrich, R. D. (2001). Entrepreneurship: Construct refinement and crosscultural validation. Journal of Business Venturing, 16(5), 495-527.

Aryee, S., Budhwar, P. S., \& Chen, Z. X. (2002). Trust as a mediator of the relationship between organizational justice and work outcomes: Test of a social exchange model. Journal of Organizational Behavior, 23(3), 267-285.

Astrachan, J. H., Klein, S. B., \& Smyrnios, K. X. (2002). The F-PEC scale of family influence: A proposal for solving the family business definition problem. Family Business Review, 15(1), 45-58.

Astrachan, J. H., \& Kolenko, T. A. (1994). A neglected factor explaining family business success: Human resource practices. Family Business Review, 7(3), 251-262.

Avey, J. B., Avolio, B. J., Crossley, C. R., \& Luthans, F. (2009). Psychological ownership: Theoretical extensions, measurement and relation to work outcomes. Journal of Organizational Behaviour, 30(2), 173-191.

Barnett, T, \& Kellermanns, F. W. (2006). Are we family and are we treated as family? Nonfamily employees' perceptions of justice in the family firm. Entrepreneurship Theory E Practice, 30(6), 837-854.

Baron, R. M., \& Kenny, D. A. (1986). The moderator-mediator variable distinction in social psychological research: Conceptual, strategic, and statistical considerations. Journal of Personality and Social Psychology, 51(6), 1173-1182.

Beehr, T. A, Drexler, J. A. J., \& Faulkner, S. (1997). Working in small family businesses: Empirical comparisons to non-family businesses. Journal of Organizational Behavior, 18(3), 297-312.

Beggan, J. K. (1992). On the social nature of nonsocial perceptions. The mere ownership effect. Journal of Personality and Social Psychology, 62(2), 229-237.

Begley, T. M., Lee, C., \& Hui, C. (2006). Organizational level as a moderator of the relationship between justice perceptions and work-related reactions. Journal of Organizational Behavior, 27(6), 705-721.

Belk, R. W. (1988). Possessions and the extended self. Journal of Consumer Research, 15(2), 139-168

Bernhard, F., \& O’Driscoll, M. P. (2011). Psychological ownership in small family-owned businesses: Leadership style and nonfamily employees' work attitudes and behaviors. Group \& Organization Management Forthcoming .

Bernhard, F., \& Sieger, P. (2009). Family influence and psychological ownership: The mediating effects of control. Paper presented at the 9th IFERA world family business research conference.

Bies, R. J., \& Moag, J. (1986). Interactional justice: Communication criteria of fairness. In R. Lewicki, B. Sheppard, \& M. Bazerman (Eds.), Research on negotiation in organizations (pp. 43-55). Greenwich: JAI Press.

Bird, B., Welsch, H., Astrachan, J. H., \& Pistrui, D. (2002). Family business research: The evolution of an academic field. Family Business Review, 15(4), 337-350.

Blondel, C., Carlock, R. S., \& Heyden, L. V. D. (2000). Fair process: Seeking justice in family firms. In P. Poutziouris (Ed.), Tradition or enterprise in the new economy. Manchester, UK: The University of Manchester Business School.

Boles, J. S. (1996). Influences of work-family conflict on job satisfaction life satisfaction and quitting intentions among business owners: The case of family-operated businesses. Family Business Review, 9(1), 61-74.

Byrne, Z. S., \& Cropanzano, R. (2001). The history of organizational justice: The founders speak. In Cropanzano, R. (Ed.). Justice in the workplace: From theory to practice (Vol. 2, pp. 3-26). Mahwah, NJ: Lawrence Erlbaum.

Carmon, A., Miller, A., Raile, A., \& Roers, M. (2010). Fusing family and firm: Employee perceptions of perceived homophily, organizational justice, organizational identification, and organizational commitment in family businesses. Journal of Family Business Strategy, 1(4), 210-223.

Carsrud, A.L. (2006). Commentary: "are We family and are we treated as family? Nonfamily employees' perceptions of justice in the family firm": It all depends on perceptions of family, fairness, equity, and justice. Entrepreneurship Theory $\mathcal{\sigma}^{\circ}$ Practice, 30(6), 855-860.

Chi, N., \& Han, T. (2008). Exploring the linkages between formal ownership and psychological ownership for the organization: The mediating role of organizational justice. Journal of Occupational and Organizational Psychology, 81(4), 691-711.

Choi, J., \& Chen, C. C. (2007). The relationship of distributive justice and compensation system fairness to employee attitudes in international joint ventures. Journal of Organizational Behavior, 28(6), 687-703.

Chrisman, J. J., Chua, J. H., \& Litz, R. (2003). A unified systems perspective of family firm performance: An extension and integration. Journal of Business Venturing, 18(4), 467-472.

Chrisman, J. J., Chua, J. H., \& Litz, R. (2004). Comparing the agency costs of family and non-family firms: Conceptual issues and exploratory evidence. Entrepreneurship Theory and Practice, 28(4), 335-354.

Chua, J. H., Chrisman, J. J., \& Sharma, P. (1999). Defining the family business by behavior. Entrepreneurship Theory \& Practice, 23(4), 19-39.

Chua, J. H., Chrisman, J. J., \& Sharma, P. (2003). Succession and nonsuccession concerns of family firms and agency relationship with nonfamily managers. Family Business Review, 16(2), 89-107.

Colquitt, J. A. (2001). On the dimensionality of organizational justice: A construct validation of a measure. Journal of Applied Psychology, 86(3), 386-400.

Colquitt, J. A., Conlon, D. E., Wesson, M. J., Porter, C. O., \& Ng, K. Y. (2001). Justice at the millennium: A meta-analytic review of 25 years of organizational justice research. Journal of Applied Psychology, 86(3), 425-445.
Cronbach, L. J. (1987). Statistical tests for moderator variables: Flaws in analyses recently proposed. Psychological Bulletin, 102(3), 414-417.

Cropanzano, R., Byrne, Z. S., Bobocel, D. R., \& Rupp, D. E. (2001). Moral virtues, fairness heuristics, social entities, and other denizens of organizational justice. Journal of Vocational Behavior, 58(2), 164-209.

Daily, C. M, Dalton, D. R., \& Rajagopalan, N. (2003). Governance through ownership: Centuries of practice, decades of research. Academy of Management Journal, 46(2), 151-158.

Davis, J. H., Allen, M. R., \& Hayes, H. D. (2010). Is blood thicker than water? A study of stewardship perceptions in family business. Entrepreneurship Theory \& Practice, 34(6), 1093-1116.

Dittmar, H. (1992). The social psychology of material possessions: To have is to be. New York: St Martin's Press.

Dutton, J. E., Dukerich, J. M., \& Harquail, C. V. (1994). Organizational images and member identification. Administrative Science Quarterly, 39(2), 239-263.

Dyer, W. G. (2003). The family: The missing variable in organizational research. Entrepreneurship: Theory \& Practice, 27(4), 401-416.

Eddleston, K. A., \& Kellermanns, F. W. (2007). Destructive and productive family relationships: A stewardship theory perspective. Journal of Business Venturing, 22(4), 545-565.

Edwards, J. R., \& Rothbard, N. P. (2000). Mechanisms linking work and family: Clarifying the relationship between work and family constructs. Academy of Management Review, 25(1), 178-199.

Erdogan, B., Liden, R. C., \& Kraimer, M. L. (2006). Justice and leader-member exchange: The moderating role of organizational culture. Academy of Management Journal, 49(2), 395-406.

Felfe, J., Six, B., Schmook, R., \& Knorz, C. (2004). Fragebogen zur Erfassung von affektivem, kalkulatorischem und normativem Commitment gegenüber der Organisation, dem Beruf/der Tätigkeit und der Beschäftigungsform (COBB). In A. Glöckner-Rist (Ed.), ZUMA Informationssystem. Elektronisches Handbuch sozialwissenschaftlicher Erhebungsinstrumente. ZIS Version 8.00: Mannheim.

Folger, R., \& Cropanzano, R. (1998). Organizational justice and human resource management. London: Sage.

Fortin, M. (2008). Perspectives on organizational justice: Concept clarification, social context integration, time and links with morality. International Journal of Management Reviews, 10(2), 93-126.

Furby, L. (1978). Possession in humans: An exploratory study of its meaning and motivation. Social Behavior and Personality, 6(1), 49-65.

Geletkanycz, M. A. (1998). The salience of "Culture's Consequences": The effect of cultural values on top executive commitment to the status quo. Strategic Management Journal, 18(8), 615-634.

Gersick, K. E., Davis, J. A., Hampton, M. M., \& Lansberg, I. (1997). Generation to generation: Life cycles of the family business. Boston: Harvard Business School Press.

Gomez-Mejia, L. R., Haynes, K. T., Nunez-Nickel, M., Jacobson, K. J. L., \& MoyanoFuentes, J. (2007). Socioemotional wealth and business risks in family-controlled firms: Evidence from Spanish olive oil mills. Administrative Science Quarterly, 52(1), 106-137.

Gomez-Mejia, L. R., Nunez-Nickel, M., \& Gutierrez, I. (2001). The role of family ties in agency contracts. Academy of Management Journal, 44(1), 81-95.

Greenberg, J. (1990). Organizational justice: Yesterday, today, and tomorrow. Journal of Management, 16(2), 399-432.

Greenberg, J. (1994). Using socially fair treatment to promote acceptance of a work site smoking ban. Journal of Applied Psychology, 79(2), 288-297.

Habbershon, T. G., Williams, M., \& MacMillan, I. C. (2003). A unified systems perspective of family firm performance. Journal of Business Venturing, 18(4), 451-465.

Hair, J. F., Black, B., Babin, B., Anderson, R. E., \& Tatham, R. L. (2006). Multivariate data analysis (6th ed.). Upper Saddle River, NJ: Prentice Hall.

Harman, H. H. (1967). Modern factor analysis. Chicago, IL: University of Chicago Press.

Heller, D., \& Watson, D. (2005). The dynamic spillover of satisfaction between work and marriage: The role of time, mood and personality. Journal of Applied Psychology, $90(6), 1273-1279$

Hollensbe, E. C., Khazanchi, S., \& Masterson, S. S. (2008). How do I assess if my supervisor and organization are fair? Identifying the rules underlying entity-based justice perceptions. Academy of Management Journal, 51(6), 1099-1116.

Ilies, R., Wilson, K. S., \& Wagner, D. T. (2009). The spillover of daily job satisfaction onto employees' family lives: The facilitating role of work-family integration. Academy of Management Journal, 52(1), 87-102.

Janssen, O., Lam, C. K., \& Huang, X. (2009). Emotional exhaustion and job performance: The moderating roles of distributive justice and positive affect. Journal of Organizational Behavior, 31(6), 787-809.

Janssen, O., \& Van Yperen, N. W. (2004). Employees' goal orientations, the quality of leader-member exchange, and the outcomes of job performance and job satisfaction. The Academy of Management Journal, 47(3), 368-384.

Jones, D. A., \& Martens, M. L. (2009). The mediating role of overall fairness and the moderating role of trust certainty in justice-criteria relationships: The formation and use of fairness heuristics in the workplace. Journal of Organizational Behavior, 30(8), 1025-1051

Judge, T. A., \& Colquitt, J. A. (2004). Organizational justice and stress: The mediating role of work-family conflict. Journal of Applied Psychology, 89(3), 395-404.

Judge, T. A., Thoresen, C. J., Bono, J. E., \& Patton, G. K. (2001). The job satisfaction-job performance relationship: A qualitative and quantitative review. Psychological Bulletin, 127(3), 376-407.

Kamptner, N. L. (1989). Personal possessions and their meanings in old age. In S. Spacapan \& S. Oskamp (Eds.), The social psychology of aging (pp. 165-196). Newbury Park, CA: SAGE. 
Kaplowitz, M. D., Hadlock, T. D., \& Levine, R. (2004). A comparison of web and mail survey response rates. Public Opinion Quarterly, 68(1), 94-101.

Kelly, L. M., Athanassiou, N., \& Crittenden, W. F. (2000). Founder centrality and strategic behavior in the family-owned firm. Entrepreneurship: Theory \& Practice, 25(2), 27-42.

Kets de Vries, M. F. R. (1993). The dynamics of family controlled firms: The good and the bad news. Organizational Dynamics, 21(3), 59-71.

Klein, S. B., Astrachan, J. H., \& Smyrnios, K. X. (2005). The F-PEC scale of family influence: Construction validation, and further implication for theory. Entrepreneurship Theory \& Practice, 29(3), 321-339.

Koch, M. J., \& McGrath, R. G. (1996). Improving labor productivity: Human resource management policies do matter. Strategic Management Journal, 17(5), 335-354

Konovsky, M. A., \& Pugh, S. D. (1994). Citizenship behavior and social exchange Academy of Management Journal, 37(3), 656-669.

Kossek, E. E., \& Ozeki, C. (1998). Work-family conflict, policies, and the job-life satisfaction relationship: A review and directions for organizational behaviorhuman resources research. Journal of Applied Psychology, 83(2), 139-149.

Kozlowski, S. W., \& Klein, K. J. (2000). A multilevel approach to theory and research in organizations: Contextual, temporal and emergent processes. In K. J. Klein \& S. W. Kozlowski (Eds.), Multilevel theory, research, and methods in organizations (pp. 349381). San Francisco: Jossey-Bass.

Lam, S. S. K., Schaubroeck, J., \& Aryee, S. (2002). Relationship between organizational justice and employee work outcomes: A cross-national study. Journal of Organizational Behavior, 23(1), 1-18.

Lansberg, I. S. (1983). Managing human resources in family firms: The problem of institutional overlap. Organizational Dynamics, 12(1), 39-46.

Lavelle, J. J., Brockner, J., Konovsky, M. A., Price, K. H., Henley, A. B., \& Taneja, A. (2009). Commitment, procedural fairness, and organizational citizenship behavior: A multifoci analysis. Journal of Organizational Behavior, 30(3), 337-357.

Lawler, E. E, \& Hall, D. T. (1970). Relationship of job characteristics to job involvement, satisfaction, and intrinsic motivation. Journal of Applied Psychology, 54(4), 305-312.

Le Breton-Miller, I., \& Miller, D. (2006). Why do some family businesses out-compete? Governance, long-term orientations, and sustainable capability. Entrepreneurship: Theory \& Practice, 30(6), 731-746.

Lee, C., Pillutla, M. M., \& Law, K. S. (2000). Power-distance, gender and organizational justice. Journal of Management, 26(4), 685-704

Lee, J. (2006). Impact of family relationships on attitudes of the second generation in family business. Family Business Review, 19(3), 175-191.

Leventhal, G. S. (1980). What should be done with equity theory? In K. J. Gergen, M. S Greenberg, \& R. H. Willis (Eds.), Social exchanges: Advances in theory and research (pp. 27-55). New York: Plenum.

Lind, E. A. (2001). Fairness heuristic theory: Justice judgments as pivotal cognitions in organizational relations. In J. Greenberg \& R. Cropanzano (Eds.), Advances in organizational justice (pp. 56-88). Stanford, CA: Stanford University Press.

Loi, R., Hang-yue, N., \& Foley, S. (2006). Linking employees' justice perceptions to organizational commitment and intention to leave: The mediating role of perceived organizational support. Journal of Occupational and Organizational Psychology, 79(1), 101-120.

Lowe, R., \& Vodanovich, S. J. (1995). A field study of distributive and procedural justice as predictors of satisfaction and organizational commitment. Journal of Busines and Psychology, 10(1), 99-114.

Lubatkin, M. H., Ling, Y., \& Schulze, W. S. (2007). An organizational justice-based view of self-control and agency costs in family firms. Journal of Management Studies, 44(6), 955-970.

Lumpkin, G. T., Martin, W., \& Vaughn, M. (2008). Family orientation: Individual-leve influences on family firm outcomes. Family Business Review, 21(2), 127-138.

MacDougall, P., \& Robinson, R. B. (1990). New venture strategies: An empirical identification of eight 'archetypes' of competitive strategies for entry. Strategic Management Journal, 11(6), 447-468.

MacKinnon, D. P., Lockwood, C. M., Hoffman, J. M., West, S. G., \& Sheets, V. (2002). A comparison of methods to test mediation and other intervening variable effects. Psychological methods, 7(1), 83-104.

Maier, G. W., Streicher, B., Jonas, E., \& Woschée, R. (2007). Gerechtigkeitseinschätzungen in Organisationen: Die Validität einer deutschsprachigen Fassung des Fragebogens von Colquitt (2001). Diagnostica, 53(2), 97-108.

Malatesta, R. M., \& Byrne, Z. S. (1997). The impact of formal and interactional justice on organizational outcomes. Paper presented at the annual meeting of the academy of management.

Masterson, S. S., Lewis, K., Goldman, B., \& Taylor, S. M. (2000). Integrating justice and social exchange: The differing effects of fair procedures and treatment on work relationships. Academy of Management Journal, 43(4), 738-748.

Masterson, S. S., \& Taylor, M. S. (1996). The broadening of procedural justice: Should interactional and procedural components be separate theories? Paper presented at the annual meeting of the academy of management.

Mayhew, M. G., Ashkanasy, N. M., Bramble, T., \& Gardner, J. (2007). A study of the antecedents and consequences of psychological ownership in organizational settings. The Journal of Social Psychology, 147(5), 477-500.

McFarlin, D. B., \& Sweeney, P. D. (1992). Distributive and procedural justice as predictors of satisfaction with personal and organizational outcomes. Academy of Management Journal, 35(3), 626-637.

Meyer, J. P., \& Allen, N. J. (1991). A three component conceptualization of organizational commitment. Human Resource Management Review, 1(1), 61-89.

Meyer, J. P., \& Allen, N. J. (1997). Commitment in the workplace: Theory research and application. Thousand Oaks, CA: Sage.
Meyer, J. P., Stanley, D. J., Herscovitch, L., \& Topolnytsky, L. (2002). Affective, continuance and normative commitment to the organization: A meta-analysis of antecedents, correlates and consequences. Journal of Vocational Behavior, 61(1), 20-52.

Michael-Tsabari, N, Lavee, Y., \& Hareli, S. (2008). Stereotypes of family businesses and their role in choosing a workplace. Paper presented at the 8th international family enterprise research academy (IFERA) Conference.

Mitchell, R. K., Morse, E. A., \& Sharma, P. (2003). The transacting cognitions of nonfamily employees in the family businesses setting. Journal of Business Venturing, 18(4), 533-551.

Nordqvist, M., \& Zellweger, T. (Eds.). (2010). Transgenerational entrepreneurship: Exploring growth and performance in family firms across generations. Cheltenham, UK and Brookfield, US: Edward Elgar.

Nunnally, J., \& Bernstein, I. (1994). Psychometric theory (Vol. 3, pp. ). ). New York: McGraw-Hill.

O'Driscoll, M. P., Pierce, J. L., \& Coghlan, A. M. (2006). The psychology of ownership: Work environment structure, organizational commitment and citizenship behaviours. Group \& Organization Management, 31(3), 388-416.

Oppenheim, A. N. (1966). Questionnaire design and attitude measurement. New York: Free Press.

Padgett, M. Y., \& Morris, K. A. (2005). Keeping it 'all in the family': Does nepotism in the hiring process really benefit the beneficiary? Journal of Leadership and Organizational Studies, 11(2), 34-45.

Pierce, J. L., \& Jussila, I. (2009). Collective psychological ownership within the work and organizational context: Construct introduction and elaboration. Journal of Organizational Behavior, 31(6), 810-834.

Pierce, J. L., Kostova, T., \& Dirks, K. (2003). The state of psychological ownership: Integrating and extending a century of research. Review of General Psychology, 7(1), 84-107.

Pierce, J. L., Kostova, T., \& Dirks, K. T. (2001). Toward a theory of psychological ownership in organizations. Academy of Management Review, 26(2), 298-310.

Pierce, J. L., O’Driscoll, M. P., \& Coghlan, A. (2004). Work environment structure and psychological ownership: The mediating effects of control. The Journal of Social Psychology, 144(5), 507-534.

Pierce, J. L., Rubenfeld, S. A., \& Morgan, S. (1991). Employee ownership: A conceptual model of process and effects. Academy of Management Review, 16(1), 121-144.

Pierce, J. L., Van Dyne, L., \& Cummings, L. L. (1992). Psychological ownership: A conceptual and operational examination. Paper presented at the southern management association proceedings.

Podsakoff, P. M., MacKenzie, S. B., Lee, J. Y., \& Podsakoff, N. P. (2003). Common method biases in behavioral research: A critical review of the literature and recommended remedies. Journal of Applied Psychology, 88(5), 879-903.

Podsakoff, P. M., \& Organ, D. W. (1986). Self-reports in organizational research: Problems and perspectives. Journal of Management, 12(4), 531-544.

Porteous, J. D. (1976). Home: The territorial core. Geographical Review, 66(4), 383-390.

Porter, M. (1985). Competitive advantage. New York: Free Press.

Price, L. L., Arnould, E. J., \& Folkman Curasi, C. (2000). Older consumers' disposition of special possessions. The Journal of Consumer Research, 27(2), 179-201.

Rousseau, D. M., \& Shperling, Z. (2003). Pieces of the action: Ownership and the changing employment relationship. Academy of Management Review, 28(4), 553-570.

Schein, E. H. (1983). The role of the founder in creating organizational culture Organizational Dynamics, 12(1), 13-28.

Schulze, W. S., Lubatkin, M. H., \& Dino, R. N. (2003). Toward a theory of agency and altruism in family firms. Journal of Business Venturing, 18(4), 473-490.

Schulze, W. S., Lubatkin, M. H., Dino, R. N., \& Buchholtz, A. K. (2001). Agency relationships in family firms: Theory and evidence. Organization Science, 12(2), 99-116.

Shapiro, D. L. (1993). Reconciling theoretical differences among procedural justice researchers by re-evaluating what it means to have one's view "considered": Implications for third-party managers. In R. Cropanzano (Ed.), Justice in the workplace: Approaching fairness in human resources management (pp. 51-78). Hillsdale, NJ: Erlbaum.

Sieger, P. (2010). How to foster entrepreneurial behavior of non-family middle-level managers: The role of psychological ownership. Paper presented at the 10th IFERA world family business research conference.

Spell, C. S., \& Arnold, T. J. (2007). A multi-level analysis of organizational justice climate, structure, and employee mental health. Journal of Management, 33(5), 724-751.

Tagiuri, R, \& Davis, J. A. (1992). On the goals of successful family companies. Family Business Review, 5(1), 43-62.

Tekleab, A. G., Takeuchi, R., \& Taylor, S. M. (2005). Extending the chain of relationships among organizational justice, social exchange, and employee reactions: The role of contract violations. Academy of Management Journal, 48(1), 146-157.

Tepper, B. J., \& Taylor, E. C. (2003). Relationships among supervisors' and subordinates' procedural justice perceptions and organizational citizenship behaviors. Academy of Management Journal, 46(1), 97-105.

Thibaut, J., \& Walker, L. (1975). Procedural justice. Hillsdale, NJ: Lawrence Erlbaum.

Tyler, T. R., \& Blader, S. L. (2000). Cooperation in groups: Procedural justice, social identity and behavioral engagement. New York: Psychology Press.

Vallejo, M. C. (2009). The effects of commitment and non-family employees of family firms from the perspective of stewardship theory. Journal of Business Ethics, 87(3) 379-390.

Van den Bos, K., Lind, E. A., \& Wilke, H. A. M. (2001). The psychology of procedural and distributive justice viewed from the perspective of fairness heuristics theory. In Cropanzano, R. (Ed.). Justice in the workplace: From theory to practice (Vol. 2, pp. 4966). Mahwah, NJ: Erlbaum. 
Van der Heyden, L., Blondel, C., \& Carlock, R. S. (2005). Fair process: Striving for justice in family business. Family Business Review, 18(1), 1-21.

Van Dyne, L., \& Pierce, J. L. (2004). Psychological ownership and feelings of possession: Three field studies predicting employee attitudes and organizational citizenship behaviour. Journal of Organizational Behaviour, 25(4), 439-459.

Wallace, J. E. (1995). Organizational and professional commitment in professional and nonprofessional organizations. Administrative Science Quarterly, 40(2), 228-255.
Walumbwa, F., Cropanzano, R., \& Hartnell, C. A. (2009). Organizational justice, voluntary learning behavior, and job performance: A test of the mediating effects of identification and leader-member exchange. Journal of Organizational Behavior, 30(8), 1103-1126.

Zhou, K. Z, Li, J. J., Zhou, N., \& Su, C. (2008). Market orientation, job satisfaction, product quality, and firm performance: Evidence from China. Strategic Management Journal, 29(9), 985-1000. 